\title{
The great Millennials' trouble: leading or confused green generation? An Italian insight
}

\author{
Michelle Bonera $^{1}$ (D) Anna Paola Codini $^{1}$ (D) Giulia Miniero ${ }^{2}$
}

Received: 23 March 2020 / Accepted: 2 November 2020 / Published online: 17 November 2020

(c) The Author(s) 2020

\begin{abstract}
The paper purpose is to investigate the green consumption behaviour of the Millennials generation. The paper aims to understand if all Italian Millennials are similar in terms of green consumption and if there are differences in adopting and consuming green products. As Millennials are considered the driving generation of the sustainable movement, thanks to their lifestyle and behaviours, our study tries to comprehend whether these consumers can be considered the leading "Green Generation". We performed a cluster analysis, using the non-hierarchical method by applying the k-medium algorithm, segmenting Millennials. The segmentation was performed according to the reasons underlying and against green consumption. Then, green values and green consumer behaviour of the segments were analyzed. The results of our research reveal the existence of different clusters of Millennial consumers in terms of green attitude. Some confusion about green issues in the Millennials generation emerges, contrasting with the literature. Our results do not necessarily imply a negative attitude towards green values by Millennials, but different green attitudes among the clusters.
\end{abstract}

Keywords Green consumption · Millennials · Green generation · Cluster analysis · Green values

Anna Paola Codini

anna.codini@unibs.it

Michelle Bonera

michelle.bonera@unibs.it

Giulia Miniero

Gminiero@fus.edu

1 Dipartimento di Economia e Management, Università degli Studi di Brescia, C.da S. Chiara 50, 25122 Brescia, Italy

2 Franklin University Switzerland, Via Ponte Tresa 29, 6904 Lugano, Switzerland 


\section{Introduction}

Over the past decades, increasing attention has been paid to the future of the planet (Kim and Choi 2005; Synodinos and Bevan-Dye 2014). Environmental sustainability has been raised at the top of the international political agenda (United Nations 2017) and has been recognized as a critical driver of innovation for companies (Nidumolu et al. 2009; Hopkins 2010).

Consumers say that manufacturers are responsible for the future of the planet (Young 2018), and this leads all companies to face the challenge of integrating environmental issues into business strategy and activities (Nidumolu et al. 2009). However, to fully realize the true potential of the green market, businesses must help consumers to change their behaviours. Green consumer behaviour is vital to the sustainability of the environment (Tobler et al. 2012). Consequently, the identification of consumers' drivers for pro-environment behaviour and the explanation of the relationship between such drivers and the pro-environment behaviour has become relevant in the literature (Wandel and Bugge 1997; Tariq 2014; Wong et al. 2014; Miniero et al. 2014).

Among consumers, Millennials are regularly considered the ones driving the sustainable movement with their lifestyle and behavioural changes (Sheahan 2005; Smith 2011; Hanson-Rasmussen and Lauver 2018). Therefore, they are also referred to as the "Green Generation". Furthermore, Millennials are more likely than any other generation to say that they would pay extra for eco-friendly and sustainable products (Young 2018).

According to this trend affecting Millennials and other generations, many brands tried to catch the appeal and quickly capitalize on these changes. For instance, UK sandwich chain Pret A Manager has now three entirely vegetarian outlets, L'Oreal has recently launched its first vegan hair colour range, and Unilever rolled out its new brand "Love Beauty and Planet", an eco and vegan-friendly brand using bottles made from recycled plastics. This experience has been fruitful, as, in 2018, Unilever declared that its "sustainable living" brands grew faster than the other businesses, leading to $70 \%$ of its turnover growth.

Despite its green image, the Millennial's consumption of green products has not been deeply researched (Smith and Brower 2012). In particular, no many studies focused on the differences within Millennials generation in terms of green consumption (Coşkun and Özbük 2019) and motivations to buy or not to buy green products. In order to fill this gap, this paper aims at describing green consumer behaviour of the Millennials generation, in order to understand if Millennials can be considered as the "Green Generation." Thanks to a cluster analysis, this paper will try to answer to this research question: are all Millennials the same in terms of green consumption? Are there differences in terms of the adoption and consumption of green products? 


\section{Theoretical background}

\subsection{Millennials generation}

Millennials have been indicated by the demographers Strauss and Howe (1991) as the generation born between 1982 and 2003. Despite the Millennials' years of birth cutoff points, that can differ according to other authors and oversimplify the differences between groups, the cohort is defined by the differentiating cultural traits as they appear to be special, sheltered, confident, conventional, team-oriented, pressured, and achieving (Strauss and Howe 1991).

They are also known as Generation Y, Next Generation, Net Generation (Shapira 2008), Generation me (Twenge and Me 2006), Echo Boomer, or New Boomer (Carlson 2009). Currently, they represent around $27 \%$ of the world population (Peterson et al. 2017) and, according to the demographic projections of the U.S. Census Bureau (Vespa and Medina 2018), in the US are on the verge of surpassing the largest generation of the last 100 years, the Baby Boomers, becoming, in turn, the largest generation of living adults in the nation. For these reasons, soon, it will find itself having a greater weight in terms of workforce, consumption, and spending capacity (Debevec et al. 2013). Concerning Millennials, it emerged that most of the research was conducted in the United States, starting from the early 1990s (Corvi et al. 2007). Equivalent studies in Europe appear to be much rarer also in 2019. Considering the characteristics that can identify Millennials, these can differ according to the birthplace, social and economic conditions, culture, and life experiences, but due to globalization, social media, the export of Western culture, they present many common traits.

It is possible to describe the Millennials as a generation with higher levels of education than previous age groups; Millennials are struggling to achieve economic independence from their family by carrying out jobs of a lower level than their qualification. They grew up during the Internet development and globalization process. Therefore, they are the most informed, demanding, and aware generation ever, they are accustomed to thinking and acting quickly (Junco and Mastrodicasa 2007; Kilian et al. 2012; Nielsen 2017). They are multitasking, and they have widespread social networks (Parment 2009; Hewlett et al. 2009). They are self-confident and goal-oriented (Howe and Strauss 2000; Twenge 2014), and they aspire to a healthy and balanced lifestyle (Valentine and Powers 2013).

Millennials show greater acceptance of cultural differences and changes with a different way of perceiving equal rights and equality (Howe 2010). Millennials value freedom of speech, self-expression, but also society by being extremely group-oriented (Muralidharan et al. 2016; Nielsen 2017). The causes behind the greater solidarity of the Millennials towards their neighbour are not attributable to a feeling of empathy. However, they lie in a less rigorous education that they have received, characterized by fewer formalities in dealing with teachers and parents. This led to a de-legitimization of the authority of institutions: the rules and way of thinking of previous generations are being considered less influencing, with 
the consequent abandonment of prejudices, on gender, race and sexual orientation (Twenge and Me 2006).

They have confidence in the possibility of creating a better future and of correcting the faults of previous generations (Eisner 2005). They accomplish tasks in order to get an endorsement for their efforts. Moreover, as they are self-absorbed and reliant and demonstrate a high sense of independence (Eisner 2005), they are less involved with behaviours that do not make them feel important or do not appeal to them (Alexander and Sysko 2012), also showing negative traits such as narcissism, cynicism and skepticism (Twenge and Me 2006).

\subsection{Millennials consumption and green consumption features}

Relatively to the Millennials' consumer cohort, they are capable of maintaining remote relationships at any time (Table 1), with friends, customers, suppliers or collaborators, breaking down all the space-time barriers existing in the past (Dimock 2018). To a lesser attachment to political and religious institutions, Millennials Generation compensates with a network of friends, colleagues and affinity groups of interest (Fry 2018; Censis 2016).

They want to know where the products they buy come from, which are the companies' policies, and they do not hesitate to compare companies, using social media (Nielsen 2017). Technology and social networks allow them to dispose of a large amount of information (Wolburg and Pokrywczynski 2001). Millennials can easily do extended online research before buying a product. It is, therefore, a dynamic target, difficult to conquer, and characterized by impatience (Alexander and Sysko 2012), being very inclined to change, to research, to constant innovation (Parment 2009; Reisenwitz and Iyer 2009; Eurispes 2017).

Moreover, marketing is a well-known field for them, and marketing activities are viewed with suspicion (Tsui and Hughes 2001). Millennials have grown up in a

Table 1 Millennials main consumption features. Source Authors elaboration

Ability to maintain remote relationships

Disposability of a large amount of information

Willingness to get information about products they

buy and to compare companies, using social media

A dynamic target, difficult to conquer, and characterized by impatience

Very inclined to change, to research, to constant innovation

Marketing is a well-known field for them, and marketing activities are viewed with suspicion

Respond to company announcements with low levels of tolerance, more brand awareness and the ability to distinguish illusion from reality

More aware of targeted advertisements

Brands tend to be less important in the purchasing decision
Dimock (2018), Fry (2018) and Censis (2016)

Wolburg and Pokrywczynski (2001)

Nielsen (2017)

Alexander and Sysko (2012)

Parment (2009), Reisenwitz and Iyer (2009) and Eurispes (2017)

Tsui and Hughes (2001)

Engebretson (2004), Ciminillo (2005), Pesquera (2005) and Valentine and Powers (2013)

Aschemann Witzel and Niebuhr Aagaard (2014)

Caplan (2005) and Phillips (2007) 
media-saturated world, bombarded since their early teens with thousands of advertisements a year (Valentine and Powers 2013). For these reasons, they respond to company announcements in a different way, with low levels of tolerance, more brand awareness and the ability to distinguish illusion from reality (Engebretson 2004; Ciminillo 2005; Pesquera 2005; Valentine and Powers 2013). Generation Y members are becoming more aware of targeted advertisements, and this makes them immune to certain communications, albeit digital (Aschemann Witzel and Niebuhr Aagaard 2014). Even brands tend to be less important in the purchasing decision (Caplan 2005; Phillips 2007). Furthermore, Millennials represent an important target for marketers concerning their high spending power (Howe and Strauss 2007).

The historical period of maximum expansion of sustainable environmental problems was precisely in the period of the birth of the Millennial generation, which grew from infancy in a climate dedicated to pro-sustainability propaganda, which was able to make them more likely to possess a green conscience (Hyllegard et al. 2011; Nielsen 2017) (Table 2). This generation has better knowledge of the environmental issue and is more concerned about saving the planet (Schmeltz 2012; Kanchanapibul et al. 2014; Casaló and Escario 2016). As Millennials are aware of the problems concerning the ecosystem, even if few young people have real in-depth knowledge on the subject, it is logical to expect that they adopt new behaviours that support sustainable development (Ivanova et al. 2019). Many studies identify a greater propensity to sustainable buying for Millennials than previous generations (Fischer et al. 2017; Hanson-Rasmussen and Lauver 2018). The results of the research by Kanchanapibul et al. (2014) show that there is a good relationship between the Millennials and the world of ecology. They want companies to have a positive impact on society more generally (Deloitte 2018). Conversely, Millennials seem to have a higher green consciousness, not necessarily leading to a green behaviour (Uyeki and Holland 2000; Diamantopoulos et al. 2003; Johnson et al. 2004; Grønhøj and Thøgersen 2012; Hume 2010). This phenomenon is known as the "green gap" (Kennedy et al. 2009; Nielsen 2017). Even if they are more likely to purchase sustainably, other personal factors can take over. Among these, parent-child relationship (Wilcock et al. 2004; Jang et al. 2011; Lappänen et al. 2012; Anvar and Venter 2014; Meeusen 2014; Muralidharan et al. 2016; Casaló and Escario 2016; Naderi and Van Steenburg 2018) modifying interest, awareness and therefore the intention to purchase green products (Kanchanapibul et al. 2014; Heo and Muralidharan 2017) can be listed.

Age, therefore, does not seem to be a sufficient structural variable to guarantee eco-compatible behaviour (Muralidharan et al. 2016). The statistical analysis shows how the influence of ecological knowledge of the younger generations is weaker than personal motivations when it comes to making the purchase decision. In particular, the price (Aschemann Witzel and Niebuhr Aagaard 2014; Covino 2017), the quality, and the availability (Bucic et al. 2012) of green products are reasons that could hinder the impact of green attitudes on sustainable purchase behaviour of the young generations. Green products are often perceived as more expansive and even less performant (Lu et al. 2013). This does not mean that other eco-sustainable characteristics are not so important for Millennials. However, traditional factors must be satisfied first, and only later ecological ones (Bollani et al. 2017) and green 
Table 2 Millennials main positive and negative green consumption features. Source Authors elaboration

Have a better knowledge of the environmental issue Schmeltz (2012), Kanchanapibul et al. (2014), and are more concerned about saving the planet

Casaló and Escario (2016), Hyllegard et al.

(2011), Nielsen (2017) and Kanchanapibul et al. (2014)

Greater propensity to sustainable buying

Ivanova et al. (2019), Fischer et al. (2017) and Hanson-Rasmussen and Lauver (2018)

Want companies to have a positive impact on society more generally

Environmental concern not necessarily leading to green behaviour

The influence of ecological knowledge is weaker than personal motivations when it comes to making the purchase decision

Deloitte (2018)

Uyeki and Holland (2000), Diamantopoulos et al. (2003), Johnson et al. (2004), Grønhøj and Thøgersen (2012), Hume (2010), Kennedy et al. (2009) and Nielsen (2017)

Wilcock et al. (2004), Jang et al. (2011), Lappänen et al. (2012), Anvar and Venter (2014), Meeusen (2014), Muralidharan et al. (2016), Casaló and Escario (2016), Naderi and Van Steenburg (2018), Kanchanapibul et al. (2014) and Heo and Muralidharan (2017)

Age does not seem to be a sufficient structural vari- Muralidharan et al. (2016) able to guarantee eco-compatible behaviour

The price of green products could hinder the impact of green attitudes on sustainable purchase behaviour

The quality and the availability of green products could hinder the impact of green attitudes on sustainable purchase behaviour

Green products are often perceived as more expansive and even less performant

Traditional factors must be satisfied first, and only later ecological ones

Green characteristics are not part of the main consideration criteria during the purchase of a product

Aschemann Witzel and Niebuhr Aagaard (2014) and Covino (2017)

Bucic et al. (2012)

Lu et al. (2013)

Bollani et al. (2017)

Bucic et al. (2012)

characteristics are not part of the main consideration criteria during the purchase of a product (Bucic et al. 2012).

\section{Research method}

\subsection{Research context}

The empirical analysis carried out describes the behaviour of Millennials generation and investigates how these consumers could be clustered according to the reasons underlying and against green consumption.

Literature dealt with green consumption through market research evidenced how some consumers show, unlike others, a clear propensity to environmentally 
friendly products (Haws et al. 2014). This suggests the existence of differences in attitudes, values, psychological characteristics affecting the factors underlying green purchasing decisions, leading to disparities consistent with purchasing behaviour. According to Burke and Davis (2014) and other authors (Mainieri et al. 1997; Roberts 1996; De Pelsmacker et al. 2005; Bezencon and Blili 2010; Leiserowitz et al. 2012; Bucic et al. 2012; Wright et al. 2014), segmentation is beneficial for companies that aim to cater their products to green consumers, as to increase the chances of doing that successfully.

Our analysis was based on a survey. The questionnaire was divided into five sections matching scales validated in other studies (Bailey et al. 2016; Burke and Davis 2014; Haws et al. 2014).

The first part consisted of seven questions collecting socio-demographic information on the respondents (gender, age, education, marital status, profession, nationality).

The second part was aimed at understanding the general consumers' attitude and sensitivity towards green issues based on the Green consumption values scale (Haws et al. 2014). The main aim of these authors was to develop a scale of values that could measure proneness to environmental sustainability and consequently to green behaviour, defined as "the tendency to express the value assigned to environmental protection through its purchasing and consumption behaviour" (Haws et al. 2014, p. 337).

Specifically, Haws et al. (2014) identified a scale of 6 green values, articulated in six statements using a Likert scale ranging from 1 to 7 , according to the level of agreement/disagreement. After examining the relationship between green and other existing environmental measures, Haws' et al. (2014), demonstrate the ability of 6 green values scale to predict relevant purchase behaviours. So, the second section of the questionnaire reported all the six items from the Haws et al. (2014) scale (a) It is important to me that the products I use do not harm the environment; (b) I consider the potential environmental impact of my actions when making many of my decisions; (c) my purchasing habits are affected by my concern for our environment; (d) I would describe myself as environmentally responsible; (e) I am concerned about wasting the resources of our planet; (f) I am willing to be inconvenienced in order to take actions that are more environmentally friendly).

The third and the fourth section of the questionnaire included 25 questions about the reasons for and against green consumption, based on the research of Burke and Davis (2014). The preliminary analysis conducted by Burke and Davis (2014) confirmed that consumers employ those reasons used for and against ethical consumption, as documented in the literature. Besides, the innovativeness of ethical products - as a motivating reason for ethical purchases -, and other additional (negative) reasons (trialability, packaging, indifference, availability, confusion, and stigma) were included, as mentioned by a participant to the preliminary analysis.

The different reasons for and against ethical consumption were measured in terms of agreement/disagreement using a scale from 1 to 7 .

Regarding the reasons for green consumption, the question was articulated as follows. "I purchase green products because": 
- it helps me fit in with my peers;

- it helps make a difference;

- they are easy to find;

- it can make me an opinion leader;

- I can save money;

- they are of a higher quality;

- they are healthier for me;

- it can help me with the creation of my positive identity;

- I genuinely care about the issues they deal with;

- they may grant me a higher status;

- they utilize innovative technology;

- I am very informed and am able to distinguish between ethical and non-ethical products.

Regarding the reasons against green consumption, the question was articulated as follows. "I reject green products, because":

- there is a monetary risk in trialing them;

- their packaging is unattractive or unappealing;

- they offer no other benefit (or product features) other than being ethical;

- I am skeptical as to how ethical these products really are;

- I don't really care about the consequences of not buying ethical products;

- I don't give them much thought;

- they are harder to find in stores;

- you have to go to specialty stores to buy them;

- I am confused as to what makes a product ethical;

- they are of a lower quality;

- they are too expensive for the value received;

- people who buy them are given a negative stigma;

- I am suffering from ethical overload;

- I am sick of hearing about it.

These reasons pro and against green consumption are the main variables employed for the cluster analysis. The fifth part of the questionnaire aimed to understand what kind of green products respondents buy and how often, using a scale ranging from 1 (never) to 5 (often). The 17 product categories selected to understand ethical purchasing behaviour were the same included in previous studies, which identified, for example, products purchased daily such as coffee (De Pelsmacker et al. 2005), chocolate (Didier and Lucie 2008) and chicken (Teisl et al. 2008). The selection also includes examples of ethical products that respondents mentioned explicitly in Burke's qualitative research (2014), including recycled paper for printers and safely caught dolphin tuna. The list was then supplemented with categories frequently appearing in online guides and mobile phone applications (e.g. GoodGuide, Inc.) informing consumers about ethical purchases (Burke and Davis 2014). 


\subsection{Data collection}

The questionnaire, including the five previous sections, was submitted directly and online via the Google Moduli involving Italian consumers from November 2018 to June 2020. Specifically, two different surveys were conducted using the same questionnaire. The first started in November 2018 and finished in January 2019, while the second started at the end of May 2020 and finished at the end of June 2020. Overall, the sample consisted of 261 respondents of Italian individuals in the 18-38 age group, so Millennials (more precisely, $86 \%$ in $18-27$ class, and $14 \%$ in $28-38$ class (Table 3).

\subsection{Data analysis}

After data collection, data were processed, and the cluster analysis was performed with the Systat programme, using the non-hierarchical method by applying the $k$-medium algorithm, and considering the reasons underlying green consumption and the reasons against green consumption as variables to segment the sample.

Table 3 Socio-demographic features of the sample

\begin{tabular}{|c|c|c|}
\hline Variables & $\begin{array}{l}\text { Number of } \\
\text { respondents }\end{array}$ & $\begin{array}{l}\text { Percentage of } \\
\text { respondents }(\%)\end{array}$ \\
\hline \multicolumn{3}{|l|}{ Gender } \\
\hline Males & 86 & 33 \\
\hline Females & 174 & 67 \\
\hline \multicolumn{3}{|l|}{ Age } \\
\hline $18-38$ & 261 & 100 \\
\hline \multicolumn{3}{|l|}{ Education } \\
\hline Lower than high school & 1 & 0 \\
\hline High school & 153 & 59 \\
\hline Graduate degree & 70 & 27 \\
\hline Postgraduate degree & 34 & 13 \\
\hline $\mathrm{PhD}$ & 1 & 0 \\
\hline \multicolumn{3}{|l|}{ Marital status } \\
\hline Unmarried & 233 & 89 \\
\hline Married/engaged & 25 & 6 \\
\hline Widowed/divorced/separated & 3 & 1 \\
\hline \multicolumn{3}{|l|}{ Kids } \\
\hline Yes & 16 & 6 \\
\hline No & 245 & 94 \\
\hline \multicolumn{3}{|l|}{ Work status } \\
\hline Student (including student worker) & 200 & 77 \\
\hline Unemployed & 17 & 7 \\
\hline Employee & 44 & 17 \\
\hline
\end{tabular}


The variables taken into consideration for the segmentation were the drivers underlying green behaviour and the reasons against green consumption (see Table 4).

The cluster analysis allowed to identify three clusters. After clustering the sample, the single clusters were investigated, matching the results of the cluster analysis with the results of the answers provided by respondents to the other sections of the questionnaire (especially Sect. 2 on green values and Sect. 5 on green consumption). Data analysis enabled to describe the feature of the identified cluster in terms of green values and green consumption. This led us to a better understanding of the green consumption behaviour of Millennials.

Table 4 List of variables used performing cluster analysis. Source Burke and Davis (2014)

\begin{tabular}{ll}
\hline & I purchase green products because \\
1. & It helps me fit in with my peers \\
2. & It helps make a difference \\
3. & They are easy to find \\
4. & It can make me an opinion leader \\
5. & I can save money \\
6. & They are of a higher quality \\
7. & They are healthier for me \\
8. & It can help me with the creation of my positive identity \\
9. & I genuinely care about the issues they deal with \\
10. & They may grant me a higher status \\
11. & They utilize innovative technology \\
12. & I am very informed and I am able to distinguish between ethical and \\
& non-ethical products \\
1. & I reject green products because \\
2. & There is a monetary risk in trialing them \\
3. & Their packaging is unattractive or unappealing \\
4. & They offer no other benefit (or product features) other than being ethical \\
5. & I am skeptical as to how ethical these products really are \\
6. & I don't really care about the consequences of not buying ethical products \\
7. & I don't give them much thought \\
8. & They are harder to find in stores \\
9. & You have to go to specialty stores to buy them \\
10. & I am confused as to what makes a product ethical \\
11. & They are of lower quality \\
12. & They are too expensive for the value received \\
13. & People who buy them are given a negative stigma \\
\hline & I am suffering from ethical overload-I am sick of hearing about it \\
\hline
\end{tabular}




\section{Findings}

\subsection{Cluster analysis}

The analysis revealed 3 clusters: cluster 1 with 76 Millennials (29\% of the sample); cluster 3 with 70 Millennials (27\%), and cluster 2 with 97-the majority of the sample (37\% of the sample), as shown in Table 5. According to the reasons behind green consumption, clusters were labelled and described as follows. Specifically, the table reports the reasons that trigger consumers to purchase and to reject green products that mostly characterize each of the three clusters. For instance, Millennials in cluster 1 purchase green products because it helps fitting

Table 5 Final cluster centers. Source Authors elaboration

\begin{tabular}{|c|c|c|c|c|}
\hline & $\begin{array}{l}\text { Cluster } 1 \\
\text { ( } 29 \% \text { of the total } \\
\text { sample) }\end{array}$ & $\begin{array}{l}\text { Cluster } 2 \\
\text { (37\% of the total } \\
\text { sample) }\end{array}$ & $\begin{array}{l}\text { Cluster } 3 \\
\text { ( } 27 \% \text { of the total } \\
\text { sample) }\end{array}$ & Assigned cluster \\
\hline \multicolumn{5}{|c|}{ Reasons to purchase green products } \\
\hline Peers & 4 & 2 & 3 & 1 \\
\hline Difference & 5 & 4 & 6 & 3 \\
\hline Easy to find & 4 & 3 & 4 & \\
\hline Opinion leader & 4 & 2 & 3 & 1 \\
\hline Save money & 4 & 2 & 3 & 1 \\
\hline Higher quality & 5 & 4 & 5 & \\
\hline Healthier & 6 & 5 & 6 & \\
\hline Positive identity & 5 & 2 & 4 & 1 \\
\hline Genuinely care & 5 & 3 & 6 & 3 \\
\hline Higher status & 4 & 2 & 3 & 1 \\
\hline Innovative technology & 5 & 4 & 4 & 1 \\
\hline Informed & 4 & 3 & 4 & \\
\hline \multicolumn{5}{|c|}{ Reasons to reject green products } \\
\hline Monetary risk & 4 & 4 & 3 & \\
\hline Packaging & 4 & 3 & 2 & 1 \\
\hline No benefit & 4 & 4 & 2 & \\
\hline Sceptical & 4 & 4 & 2 & \\
\hline No care & 3 & 4 & 2 & 2 \\
\hline No thought & 4 & 4 & 2 & \\
\hline Find in store & 4 & 4 & 3 & \\
\hline Specialty store & 4 & 5 & 4 & 2 \\
\hline Confused & 4 & 4 & 2 & \\
\hline Lower quality & 3 & 3 & 2 & 2 \\
\hline Too expensive & 4 & 5 & 3 & 1 \\
\hline Negative stigma & 3 & 2 & 1 & \\
\hline Overload & 3 & 3 & 2 & \\
\hline
\end{tabular}


in with peers. The right column in the table, indeed, reports for each reason for buying/not buying green products, the "assigned cluster".

\subsubsection{Cluster 1: "Social Green" ( $29 \%$ of the total sample)}

These consumers state that purchasing green products helps them fit in with their peers, makes them opinion leaders, helps them to save money, to create a positive identity, and grants a higher status. Besides, they declare to buy green products also because of their innovative technology. According to these answers, these consumers seem to be green not for the planet but just for themselves. They strongly care about showing off their green consumption, as this empowers their social status. This general attitude is also supported by the reasons not to buy green products. These consumers identify the unattractive and unappealing packaging and the negative stigma as the main reasons for rejecting green products. For these reasons, the label assigned to these consumers is "Social Green".

\subsubsection{Cluster 2: "Surely not Green" (37\% of the total sample)}

In this case, respondents clearly identify specific reasons for rejecting green products. First, they state that they do not really care about the consequences of not buying green products, they have to go to specialty stores to buy them, and these products are too expensive for the value received. Otherwise, no specific reasons to buy green products emerge. For these reasons, the label assigned to these consumers is "Surely not Green".

\subsubsection{Cluster 3: "Really Green" ( $27 \%$ of the total sample)}

For this group of consumers, purchasing green products helps make a difference. They also declare to care genuinely about the issues these products deal with. For these reasons, the label assigned to these consumers is "Really Green".

Thanks to the data collected during the survey regarding the socio-demographic features, green attitudes, and green consumption, clusters were further described allowing us to address the research question better, as to say: can Millennials be considered the leading and real "Green Generation"?.

\subsection{Millennials' green values}

Regarding the green values scale, the average scores (Table 6) assigned to each proposition of the second section of the questionnaire were analyzed to understand what are the attitude and opinion, within each cluster. The scores refer to a scale going from a minimum of 1 ("totally disagree") to a maximum of 7 ("totally agree).

The high scores assigned by all the clusters to the green values support a general sensitivity and a positive attitude towards green issues by all the Millennials included in the analysis. Regardless, looking at the average scores in the different clusters, the lowest scores assigned to green values were in cluster 2 ("Surely not 


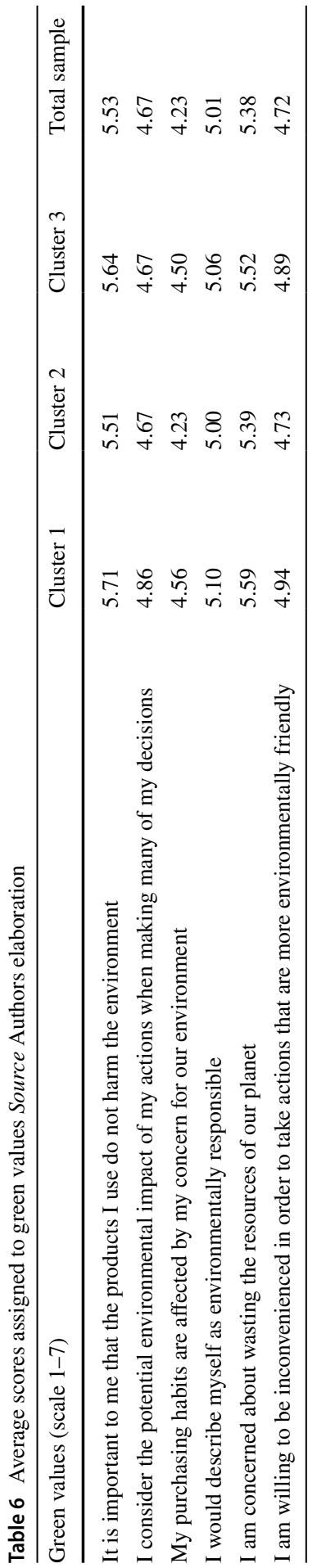


Green"), assuming low values compared to the average score of the sample and the average scores assigned by the other two clusters. At the same, the highest average scores are in cluster 1, defined as the cluster of "Social Green" Millennials, confirming this cluster as a "green" cluster. This is the same for cluster 3 , reporting the higher average scores after cluster 1 , also confirming this as a "green" cluster.

Having a look at the single items included in the table, something interesting regarding the green consumption in Millennials generation emerges. Regardless the cluster, for all the groups, scores are higher $(>5)$ for the items affecting the green attitude ("It is important to me that the products I use do not harm the environment", "I would describe myself as environmentally responsible", "I am concerned about wasting the resources of our planet"). On the other side, the scores affecting green behaviour ("I consider the potential environmental impact of my actions when making many of my decisions", "My purchasing habits are affected by my concern for our environment", "I am willing to be inconvenienced to take actions that are more environmentally friendly"), even if high, generally decrease $(<5)$. This might be consistent with an attitude-behaviour gap in Millennials, as, despite a positive attitude towards green issues, this attitude does not result in concrete behaviour.

\subsection{Millennials' green consumer behaviour}

As previously described, the value assigned to environmental protection does not necessarily lead to green consumer behaviour. It is, therefore, necessary to analyze the green consumption in each cluster. The data of the fifth part of the questionnaire were elaborated to show the frequency of green purchasing in each of the identified clusters.

The percentage of those who sometimes, often, or always buy green products in "Social Green" $(48,99 \%)$ and "Really Green" (56,35\%) clusters is higher compared to those who buy green products with the same frequency belonging to the "Surely not Green" cluster $(31,62 \%)$. This supports the fit of cluster analysis conducted in the first part, as those who assigned high scores to green values in the second part of the questionnaire, and who belong to "Social Green" and "Really Green" clusters, actually show a greener consumer behaviour than the respondents belonging to the second cluster.

Secondly, it is interesting to observe how, comparing the buying behaviours of consumers belonging to the same cluster, the green consumer behaviour mostly differs.

The trends of the frequencies reported in Fig. 1 refer to the purchasing of environmentally safe dishwashing liquid. Even though results slightly change according to the kind of product selected for the analysis, it is surprising that, for instance in the "Social Green" segment, Millennials declaring to never or rarely buy environmentally safe dishwashing liquid are $32.89 \%$ of the cluster. In "Really Green" cluster, this percentage is $35.71 \%$ of the cluster, while in "Surely not Green" cluster this goes up to $68.04 \%$. This is consistent with the general features of the cluster. 


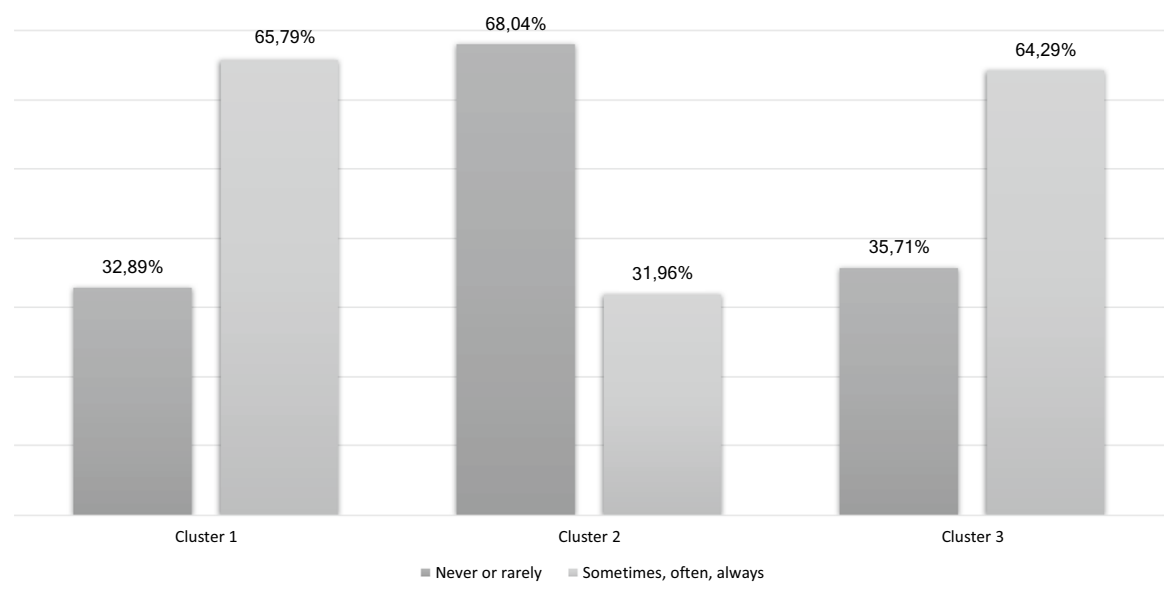

Fig. 1 Consumption of environmentally safe dishwashing liquid. Source Authors elaboration

\section{Conclusions}

The purpose of the empirical study was to investigate the attitude and the reasons behind the green consumption behaviour of the Millennials generation.

Data analysis performed hitherto gives an interesting contribution to the literature devoted to green consumption and suggests some managerial implications.

The first result of the empirical analysis contrasts with the literature and empirical evidence, usually describing Millennials as pro-environment oriented (Smith and Brower 2012; Eumetra Monterosa 2017; GWI 2018). On the other hand, our findings do not support the theories evidencing the existence of a negative correlation between young generations and environmental sensitivity (Van Liere 1981; Zimmer et al. 1994; Finisterra do Paço and Raposo 2010).

In particular, different green attitudes and behaviours were evidenced by the high number of respondents included in the second cluster of "Surely not Green" (37\%). Similar evidence emerged even analyzing the scores assigned by the respondents to green values, and those regarding the green consumer behaviour. Besides, the high percentage of consumers belonging to cluster 1 defined as "Social Green" reveals something interesting about the green consumption in Millennials generation. This cluster, indeed, seems to be "green" not for feeling a devotion towards the planet, but mostly for showing off this attitude. This might be consistent with the general attitude of Millennials to be "self-oriented" (Naderi and Van Steenburg 2018) that, in this case, lead to exhibit green consumption as synonymous of social status.

Our results do not necessarily imply a negative attitude towards green values by Millennials, but of course different green attitudes in the three clusters. This is also supported by the analysis of green consumption in each cluster.

Focusing on managerial implications, although the segment of "Surely not green" seems to be the least attractive for green marketers, these are the ones requiring more attention. Information and knowledge are necessary to ensure that these consumers develop an adequate sensitivity to the surrounding environment so that they 
can no longer judge based on prejudices, sometimes depending on previous experiences of "greenwashing". Additionally, "Social Green" might be a strategic target, influencing skeptical consumers going green.

\section{Limitation of the research}

First, investigating the drivers of green consumption and the reasons against green consumption, the differences emerging according to the different product categories were not analyzed. For example, the health concern might prevail in the consumption of product categories such as food or detergents, while the status might be more relevant for other categories such as clothing.

Another limitation of our study is that the interviewees may have overestimated or underestimated the reasons behind the positive or negative attitudes, as well as the frequency with which certain products are purchased.

Finally, the behaviour and attitudes of Millennials in the cluster analysis were not compared with other categories of respondents. In order to overcome this limitation, future research will compare Millennials with all the other generations, including $\mathrm{Z}$ generation, completely neglected in this analysis.

Moreover, since the participants in this first survey are all Italian, it would be interesting to include a comparison with consumers of different nationalities.

Funding Open access funding provided by Università degli Studi di Brescia within the CRUI-CARE Agreement.

\section{Compliance with ethical standards}

Conflict of interest All the authors declare that they have no conflict of interest.

Ethical approval All procedures performed in studies involving human participants were in accordance with the ethical standards of the institutional and/or national research committee and with the 1964 Helsinki declaration and its later amendments or comparable ethical standards.

Informed consent Informed consent was obtained from all individual participants included in the study.

Open Access This article is licensed under a Creative Commons Attribution 4.0 International License, which permits use, sharing, adaptation, distribution and reproduction in any medium or format, as long as you give appropriate credit to the original author(s) and the source, provide a link to the Creative Commons licence, and indicate if changes were made. The images or other third party material in this article are included in the article's Creative Commons licence, unless indicated otherwise in a credit line to the material. If material is not included in the article's Creative Commons licence and your intended use is not permitted by statutory regulation or exceeds the permitted use, you will need to obtain permission directly from the copyright holder. To view a copy of this licence, visit http://creativecommons.org/licen ses/by/4.0/. 


\section{References}

Alexander, C. S., \& Sysko, J. M. (2012). A study of the cognitive determinants of generation Y's entitlement mentality. Academy of Educational Leadership Journal, 16(2), 63-68.

Anvar, M., \& Venter, M. (2014). Attitudes and purchase behaviour of green products among generation y consumers in South Africa. Mediterranean Journal of Social Sciences, 5(21), 183-194.

Aschemann Witzel, J., \& Niebuhr Aagaard, E. M. (2014). Elaborating on the attitude-behaviour gap regarding organic products: Young Danish consumers and in-store food choice. International Journal of Consumer Studies, 38(5), 550-558.

Bailey, A., Mishra, A., \& Tiamiyu, M. (2016). GREEN consumption values and Indian consumers' response to marketing communications. Journal of Consumer Marketing, 33(7), 562-573.

Bezencon, V., \& Blili, S. (2010). Ethical products and consumer involvement: What's new? European Journal of Marketing, 44(9/10), 1305-1321.

Bollani, L., Peira, G., Varese, E., Nesi, E., Pairotti, M. B., \& Bonadonna, A. (2017). Labelling and sustainability in the green food economy: Perception among Millennials with a good cultural background. Rivista di studi sulla sostenibilità.

Bucic, T., Harris, J., \& Arli, D. (2012). Ethical consumers among the Millennials: A cross-national study. Journal of Business Ethics, 110(1), 113-131.

Burke, P. F., \& Davis, C. E. S. (2014). Segmenting consumers' reasons for and against ethical consumption. European Journal of Marketing, 48(11/12), 2237-2261.

Caplan, E. (2005). Brand loyalty. Dealerscope, 60, May 20, 60.

Carlson, E. (2009). 20th-century US generations. Washington, DC: Population Reference Bureau.

Casaló, L. V., \& Escario, J. J. (2016). Intergenerational association of environmental concern: Evidence of parents' and children's concern. Journal of Environmental Psychology, 48, 65-74.

Censis. (2016). Vita da Millennial: web, new media, startup e molto altro. Nuovi soggetti della ripresa italiana alla prova.

Ciminillo, J. A. (2005). Elusive Generation Y demands edgier marketing. Automotive News, 79(6144), 28B.

Corvi, E., Bonera, M., \& Bigi, A. (2007). Are the Italian Millennials Similar or Different from the US Millennials?. Conference proceedings Seventh International Business Conference, Sidney, Australia, 3-6 December.

Coşkun, A., \& Özbük, R. M. Y. (2019). Environmental segmentation: Young Millennials' profile in an emerging economy. Young Consumers.

Covino, R. M. (2017). Are you appealing to fresh and healthy Millennials? Convenience Store News.

De Pelsmacker, P., Driesen, L., \& Rayp, G. (2005). Do consumers care about ethics? Willingness to pay for fair-trade coffee. The Journal of Consumer Affairs, 39(2), 363-385.

Debevec, K., Schewe, C., Madden, T., \& Diamond, W. (2013). Are today's Millennials splintering into a new generational cohort? Maybe! Journal of Consumer Behaviour, 12, 20-31.

Deloitte. (2018). Deloitte Millennial survey. Retrieved from https://www2.deloitte.com/content/dam/ Deloitte/global/Documents/About-Deloitte/gx-2018-millennial-survey-report.pdf. downloaded 2019, December 15.

Diamantopoulos, A., Schlegelmilch, B. B., Sinkovics, R. R., \& Bohlen, G. M. (2003). Can socio-demographics still play a role in profiling green consumers? A review of the evidence and an empirical investigation. Journal of Business Research, 56(6), 465-480.

Didier, T., \& Lucie, S. (2008). Measuring consumer's willingness to pay for organic and fair trade products. International Journal of Consumer Studies, 32(5), 479-490.

Dimock, M. (2018). Defining generations: Where Millennials end and post-Millennials begin. Pew Research Center. http://www.pewresearch.org/fact-tank/2018/03/01/defining-generations-where -millennials-end-and-post-millennials-begin/.

Eisner, S. (2005). Managing generation Y. S.A.M. Advanced Management Journal, 70(4), 4-15.

Engebretson, J. (2004). Odd gen out. American Demographics, 24(4), 14-18.

Eumetra Monterosa. (2017). https://www.lifegate.it/persone/news/osservatorionazionale-sostenibil ita-2017.

Eurispes. (2017). Ri2017 Documento di sintesi: $29^{\circ}$ rapporto Italia.

Finisterra do Paço, A. M., \& Raposo, M. L. B. (2010). Green consumer market segmentation: Empirical findings from Portugal. International Journal of Consumer Studies, 34, 429-436. 
Fischer, D., Böhme, T., \& Geiger, S. M. (2017). Measuring young consumers' sustainable consumption behaviour: Development and validation of the YCSCB scale. Young Consumers, 18, 312-326.

Fry, R. (2018). Millennials are the largest generation in the U.S. Labor force, Pew Research Center. http:// www.pewresearch.org/fact-tank/2018/04/11/millennials-largest-generation-us-labor-force/.

Global Web Index. (2018). The rise of green consumerism: What do brands need to know?

Grønhøj, A., \& Thøgersen, J. (2012). Action speaks louder than words: The effect of personal attitudes and family norms on adolescents' pro-environmental behaviour. Journal of Economic Psychology, 33, 292-302.

Hanson-Rasmussen, N. J., \& Lauver, K. J. (2018). Environmental responsibility: Millennial values and cultural dimensions. Journal of Global Responsibility, 9(1), 6-20.

Haws, K. L., Winterich, K. P., \& Naylor, R. W. (2014). Seeing the world through GREEN-tinted glasses: Green consumption values and responses to environmentally friendly products. Journal of Consumer Psychology, 24(3), 336-354.

Heo, J., \& Muralidharan, S. (2017). What triggers young Millennials to purchase eco-friendly products? The interrelationships among knowledge, perceived consumer effectiveness, and environmental concern. Journal of Marketing Communications, 1-17.

Hewlett, S. A., Sherbin, L., \& Sumberg, K. (2009). How generation and baby boomers will reshape your agenda. Harvard Business Review, 71-77.

Hopkins, M. S. (2010). How sustainability fuels design innovation. MIT Sloan Management Review, 52(1), $75-81$.

Howe, N. (2010). Meet Mr. and Mrs. Gen X: A new parent generation. AASA-The School Superintendents Association.

Howe, N., \& Strauss, W. (2000). Millennials rising: The next greatest generation. New York, NY: Vintage Books.

Howe, N., \& Strauss, W. (2007). The next 20 years: How customer and workforce attitudes will evolve. Harvard Business Review, 85(7-8), 41-52.

Hume, M. (2010). Compassion without action: Examining the young consumers consumption and attitude to sustainable consumption. Journal of World Business, 45(4), 385-394.

Hyllegard, K., Yan, R., Ogle, J., \& Attmann, J. (2011). The influence of gender, social cause, charitable support, and message appeal on Gen Y's responses to cause-related marketing. Journal of Marketing Management, 27(1/2), 100-123.

Istat. (2016). Classificazione delle generazioni. Statistiche sperimentali. https://www.istat.it/it/files//2011/01/ Generazioni-nota.pdf.

Ivanova, O., Flores-Zamora, J., Khelladi, I., \& Ivanaj, S. (2019). The generational cohort effect in the context of responsible consumption. Management Decision, 57(5), 1162-1183.

Jang, Y. J., Kim, W. G., \& Bonn, M. A. (2011). Generation Y consumers' selection attributes and behavioral intentions concerning green restaurants. International Journal of Hospitality Management, 30(4), 803-811.

Johnson, C. Y., Bowker, J. M., \& Cordell, H. K. (2004). Ethnic variation in environmental belief and behavior: An examination of the new ecological paradigm in a social psychological context. Environment and Behavior, 36, 157-186.

Junco, R., \& Mastrodicasa, J. M. (2007). Connecting to the net generation: What highereducation professionals need to know about today's students. Washington, DC: NASPA.

Kanchanapibul, M., Lacka, E., Wang, X., \& Chan, H. K. (2014). An empirical investigation of green purchase behaviour among the young generation. Journal of Cleaner Production, 66, 528-536.

Kennedy, E. H., Beckley, T. M., McFarlane, B. L., \& Nadeau, S. (2009). Rural urban differences in environmental concern in Canada. Rural Sociology, 74(3), 309-329.

Kilian, T., Hennigs, N., \& Langner, S. (2012). Do Millennials read books or blogs? Introducing a media usage typology of the Internet generation. Journal of Consumer Marketing, 29(2), 114-124.

Kim, Y., \& Choi, S. M. (2005). Antecedents of green purchase behavior: An examination of collectivism, environmental concern, and PCE. ACR North American Advances.

Lappänen, J. M., Haahla, A. E., Lensu, A. M., \& Kuitunen, M. T. (2012). Parent-child similarity in environmental attitudes: A pairwise comparison. The Journal of Environmental Education, 43(3), 162-176.

Leiserowitz, A., Maibach, E., Roser-Renouf, C., \& Hmielowski, J. (2012). Global warming's six Americas, Yale University and George Mason University, New Haven, CT, Yale Project on Climate Change Communication. http://environment.yale.edu/climatecommunication/files/Six-Americas-March-2012.pdf. Accessed 25 September 2013. 
Lu, L., Bock, D., \& Joseph, M. (2013). Green marketing: What the Millennials buy. Journal of Business Strategy, 34(6), 3-10.

Mainieri, T., Barnett, E. G., Valdero, T. R., Unipan, J. B., \& Oskamp, S. (1997). Green buying: The influence of environmental concern on consumer behaviour. The Journal of Social Psychology, 137(2), 189-204.

Meeusen, C. (2014). The intergenerational transmission of environmental concern: The influence of parents and communication patterns within the family. Journal of Environmental Education, 45(4), 77-90.

Miniero, G., Codini, A., Bonera, M., Corvi, E., \& Bertoli, G. (2014). Being green: from attitude to actual consumption. International Journal of Consumer Studies, 38(5), 521-528.

Muralidharan, S., Rejón-Guardia, F., \& Xue, F. (2016). Understanding the green buying behaviour of younger Millennials from India and the United States: A structural equation modeling approach. Journal of International Consumer Marketing, 28(1), 54-72.

Naderi, I., \& Van Steenburg, E. (2018). Me first, then the environment: Young Millennials as green consumers. Young Consumers, 19(3), 280-295.

Nidumolu, R., Prahalad, C. K., \& Rangaswami, M. R. (2009). Why sustainability is now the key driver of innovation. Harvard Business Review, 43, 57-64.

Nielsen. (2017). Millennial: Dai!, The Nielsen Company (Italy) S.r.1.. 3, 337-347.

Parment, A. (2009). Die Generation Y-Mitarbeiter der Zukunft. Wiesbaden: Gabler.

Pesquera, A. (2005). Reaching Generation Y. San Antonio Express-Newsz, 29(1).

Peterson, E. R., Sillman, A., \& McCaffrey, C. R. (2017). Where are the global Millennials?. AT KearneyGlobal Business Policy Council (GBPC). Available at www.atkearney.com/web/global-businesspolicycouncil/article.

Phillips, C. (2007). Millennials: Clued in or clueless. Advertising age, 78(46), 12-13.

Reisenwitz, T. H., \& Iyer, R. (2009). Differences in generation x and generation y: Implications for the organization and marketers. Marketing Management Journal, 19(2), 91-103.

Roberts, J. A. (1996). Will the real socially responsible consumer please step forward? Business Horizons, 39(1), 79-84.

Schmeltz, L. (2012). Consumer-oriented CSR communication: Focusing on ability or morality? Corporate Communications: An International Journal, 17(1), 29-49.

Shapira, I. (2008). What comes next after generation X? The Washington Post, 6.

Sheahan, P. (2005). Generation Y: Thriving and surviving with generation Y at work. Prahan: Hardie Grant Books.

Smith, B. (2011). Who shall lead us? How cultural values and ethical ideologies guide young marketers' evaluations of the transformational manager-leader. Journal of Business Ethics, 100(4), 633-645.

Smith, K. T., \& Brower, T. R. (2012). Longitudinal study of green marketing strategies that influence Millennials. Journal of Strategic Marketing, 20(6), 535-551.

Strauss, W., \& Howe, N. (1991). Generations: The history of America's Future, 1584 to 2069. New York: William Morrow and Company.

Synodinos, C., \& Bevan-Dye, A. (2014). Determining African Generation Y students' likelihood of engaging in pro-environmental purchasing behaviour. Mediterranean Journal of Social Sciences, 5(21), 101-109.

Tariq, M. Z. (2014). Impact of green advertisement and green brand awareness on green satisfaction with mediating effect of buying behavior. Journal of Managerial Sciences, 8(2), 274-289.

Teisl, M. F., Radas, S., \& Roe, B. (2008). Struggles in optimal labelling: How different consumers react to various labels for genetically modified foods. International Journal of Consumer Studies, 32(5), $447-456$.

Tobler, C., Visschers, V. H., \& Siegrist, M. (2012). Addressing climate change: Determinants of consumers' willingness to act and to support policy measures. Journal of Environmental Psychology, 32(3), 197-207.

Tsui, B., \& Hughes, L. Q. (2001). Generation next. Advertising Age, 72(3), 14-16.

Twenge, J. M. (2014). Generation me-revised and updated: Why today's young Americans are more confident, assertive, entitled - and more miserable than ever before. New York: Simon and Schuster.

Twenge, J., \& Me, G. (2006). Why today's young Americans are more confident. Assertive, entitled-and more miserable than ever before. Atria Paperback.

United Nation. (2017). World population prospects. Key findings and advance tables. https://esa.un.org/unpd/ wpp/publications/files/wpp2017_keyfindings.pdf.

Uyeki, E. S., \& Holland, L. J. (2000). Diffusion of pro-environment attitudes? American Behavioral Scientist, 43(4), 646-662.

Valentine, D. B., \& Powers, T. L. (2013). Generation Y values and lifestyle segments. Journal of Consumer Marketing, 30(7), 597-606. 
Van Liere, (1981). Environmental concern: Does it make a difference how it's measured? Environment and Behavior, 13(6), 651-676.

Vespa, J., Armstrong D. M., \& Medina, L. (2018). Demographic turning points for the United States: Population projections for 2020 to 2060. Current Population Reports, P25-1144, U.S. Census Bureau, Washington, DC.

Wandel, M., \& Bugge, A. (1997). Environmental concern in consumer evaluation of food quality. Food Quality and Preference, 8(1), 19-26.

Wilcock, A., Pun, M., Khanona, J., \& Aung, M. (2004). Consumer attitudes, knowledge and behaviour: A review of food safety issues. Trends in Food Science and Technology, 15(2), 56-66.

Wolburg, J. M., \& Pokrywczynski, J. (2001). A psychographic analysis of Generation Y college students. Journal of Advertising Research, 41(5), 33-52.

Wong, C. W. Y., Lai, K. H., Shang, K. C., \& Lu, C. S. (2014). Uncovering the value of green advertising for environmental management practices. Business Strategy and the Environment, 23(2), 117-130.

Wright, M. J., Teagle, D. A. H., \& Feetham, P. M. (2014). A quantitative evaluation of the public response to climate engineering. Nature Climate Change, 4, 106-110.

Young, K. (2018). The rise of green consumerism: What do brands need to know? GlobalWebIndex Q2 2018. https://www.globalwebindex.net.

Zimmer, M. R., Stafford, T. F., \& Stafford, M. R. (1994). Green issues: Dimensions of environmental concern. Journal of Business Research, 30(1), 63-74.

Publisher's Note Springer Nature remains neutral with regard to jurisdictional claims in published maps and institutional affiliations. 